\title{
Görsel Sanatlar Öğretmeni İstihdamında Öğretmenlik Alan Bilgisi Testinin Gerekliliği ve KPSS’ye Yönelik Algı Ölçeği Geliştirme Çalışması
}

\section{The Visual Arts Teacher's Needs to Teacher's Knowledge Test for Employing Teachers and Perception Scale Development Study for PPSE}

\author{
Meliha YILMAZ \\ Gazi Üniversitesi, Gazi Ĕ̆itim Fakültesi, Güzel Sanatlar Eğitimi Bölümü, Resim - Işs Ĕ̆itimi A.B.D., Ankara. \\ e-posta: ameliha@gazi.edu.tr \\ Kerim LAÇİNBAY \\ Gazi Üniversitesi, Ĕ̆itim Bilimleri Enstitüsü, Ankara. \\ e-posta:kerimlacinbay@gazi.edu.tr \\ Hüseyin ELMAS \\ Selçuk Üniversitesi, Güzel Sanatlar Fakültesi, Resim Bölümü, Konya. \\ e-posta:helmas@selcuk.edu.tr

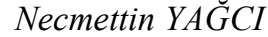 \\ Gazi Üniversitesi, Gazi Ĕ̆itim Fakültesi, Güzel Sanatlar Eğitimi Bölümü, Resim - Işs Ĕgitimi A.B.D., Ankara. \\ e-posta:nyagci@gazi.edu.tr
}

\begin{abstract}
Atıf: Yılmaz, M., Laçinbay, K.., Elmas, H. \& Yağc1, N. (2018). Görsel Sanatlar Öğretmeni İstihdamında Öğretmenlik Alan Bilgisi Testinin Gerekliliği ve KPSS'ye Yönelik Algı Ölçeği Geliştirme Çalışması. E-Kafkas Eğitim Araştırmaları Dergisi, 5(2), 40-49.
\end{abstract}

Gönderi Tarihi: $22-06-2018$

Kabul Edilme Tarihi: $28-08-2018$

DOI: $10.30900 /$ kafkasegt.435702

\section{$\ddot{\text { ozet }}$}

$\mathrm{Bu}$ araştırmada amaç görsel sanatlar öğretmeni istihdamında öğretmenlik alan bilgisi testinin (ÖABT) gerekliğini ortaya koymak ve bu alanda KPSS'ye yönelik alg1 ölçeği geliştirmektir. Ölçeğin geliştirilmesi için çalışma grubunu Gazi Üniversitesi, Gazi Eğitim Fakültesi, Güzel Sanatlar Eğitimi Bölümü, Resim - İş Eğitimi Anabilim Dalı'nda öğrenim görmekte olan; 3. sınıf öğrencisi (40 kişi), 4. sınıf öğrencisi (50 kişi), pedagojik formasyon grubu öğrencisi (36 kişi) ve ilgili anabilim dalı mezunu (17 kişi) olmak üzere toplamda 143 kişi oluşturmaktadır. Yapılan geçerlik analizleri sonucunda 4 madde ölçme aracından çıkarılmış ve 3 alt faktör (ÖABT'ye Yönelik Algılar - KPSS'nin Kapsamına Yönelik Algılar Lisans Öğrenimi ve KPSS Yeterliği Algisı) ve toplam 23 maddeden oluşan nihai form elde edilmiştir. Görsel Sanatlar Öğretmen Adayları İçin KPSS ve ÖABT Algısı Ölçeği'nin üç alt boyutu ile birlikte toplam varyansın 45,1'ini açıkladığı görülmüştür. Yapılan güvenirlik analizleri sonucunda ilgili ölçeğin birinci alt boyutuna (ÖABT'ye Yönelik Algılar) ilişkin Cra katsayısı ,85; ikinci alt boyutuna (KPSS'nin Kapsamına Yönelik Algılar) ilişkin Cra katsayısı ,74; son olarak üçüncü alt boyutuna (Lisans Öğrenimi ve KPSS Yeterliği Algısı) ilişkin Cra katsayısı ,77 olarak bulunmuştur. Ölçeğin geneline ilişkin Cra katsayısı ise ,79 olarak bulunmuştur. Görsel Sanatlar Öğretmen Adayları İçin KPSS Algısı Ölçeği'nin geçerli ve güvenilir bir ölçme aracı olduğu söylenebilir.

Anahtar kelimeler: öğretmen, görsel sanatlar, KPSS, ÖABT.

\begin{abstract}
The purpose of this research is to reveal the necessity of testing teachers' departmental proficiency (TDPT) in visual arts for employment, and to develop perception scale for PPSE (KPSS). When the literature is examined, the necessity TDPT (ÖABT) in the visual arts teacher employment has been revealed. Study group of the research consists of 143 students studying at Gazi University, Gazi Education Faculty, Department of Visual Arts Education, among which 40 are from 3rd grade, 50 are from 4th grade, 36 are from pedagogical formation group and 17 are from graduated students from related departments. As a result of the factor analysis, 4 items were extracted from the scale and a final form that consiss of 23 items and 3 sub factors is created. The first of the sub-factors is called as "Perceptions for TDPT", the second as "Perceptions for the Scope of PPSE" and the third as "Perception of Undergraduate Learning and PPSE Sufficiency". It can be seen that PPSE
\end{abstract}


and TDPT Perception Scale for Visual Arts Teacher Candidates explains 45,1 of the total variance. As a result of the reliability analysis, the Cr $\alpha$ coefficient for the first sub-dimension is found to be 0.85 ; the Cr $\alpha$ coefficient for the second subdimension is 0.74; and for the third sub-dimension the Cr $\alpha$ coefficient is 0.77 . The Cr $\alpha$ coefficient for the overall scale is 79 . It can be said that the relevant scale is a valid and reliable measuring instrument.

Keywords: teacher, visual arts, PPSE, TDPT.

\section{GİRiş}

Eğitim, mevcut değerleri yeni kuşaklara aktararak sosyalleşmeyi, bireysel yeteneklerin keşfedilmesi ve geliştirilmesinde bireye yardım ederek kişilik kazanmasını, hayatını sürdürebilmek ve toplumsal yaşama katkıda bulunmak üzere, bireylerin ihtiyaç duyacağı bilgi, beceri ve davranışlar ile iş görme alışkanlığı kazandırarak meslek sahibi olmalarını sağlamak gibi birçok önemli işlevi yerine getirir. Eğitim sistemlerinin bu temel işlevleri etkin olarak yerine getirebilmesi, sistem içerisinde yer alan öğretmenlerin niteliğine bağlıdır. Bu nedenle bir ülkede eğitimle ilgili çıktıları iyileştirmenin yolu, öncelikle öğretmen niteliklerini geliştirmekten geçmektedir (MEB, 2017:1). Öğretmen niteliklerinin geliştirilmesinin yollarından biri de, öğretmenin çok farklı açılardan sahip olması gereken bilgi, beceri, tutum ve değerlerin yeterliliğini ölçmesi gereken sınavlardır. Çünkü bu durum, öğretmen adaylarının mesleğe başlayabilmek için gerekli donanımı elde edebilme amacına dönük çabalarını da beraberinde getirir.

Öğretmenlik mesleğine kaynak teşkil eden bölümlerden mezun olan kişilerin Millî Eğitim Bakanlığı'nda öğretmen olarak istihdam edilebilmelerine yönelik olarak Kamu Personeli Seçme Sınavı (KPSS), Öğretmenlik Alan Bilgisi Testi (ÖABT) ve sözlü gibi çeşitli sınavlar gerçekleştirilmektedir. Söz konusu sınavların Öğretmenlik Mesleği Genel Yeterlikleri çerçevesinde sahip olunması gereken Mesleki bilgi, Mesleki beceri ile tutum ve değerleri ölçebilecek şekilde yeniden yapılandırılması üniversite mezunları arasından öğretmenlik konusunda en yetenekli olanların istihdamını sağlayacaktır. (MEB, 2017:10).

Alan Bilgisi Yeterliğine sahip öğretmen Tablo 1'de görüldüğü üzere (MEB, 2017:8); “alanında sorgulayıcı bakış açısını kapsayacak şekilde ileri düzeyde kuramsal, metodolojik ve olgusal bilgiye sahiptir".

Alan Eğitimi Bilgisi Yeterliğine sahip öğretmen ise; "Alanının öğretim programına ve pedagojik alan bilgisine sahiptir”.

Tablo 1.

Öğretmenlik mesleği genel yeterlikleri

\begin{tabular}{lll}
\hline & Mesleki Beceri & Tutum ve Değerler \\
\hline A1. Alan Bilgisi & B1. Eğitim Öğretimi Planlama & $\begin{array}{l}\text { C1. Milli, Manevi ve Evrensel } \\
\text { Değerler }\end{array}$ \\
\hline
\end{tabular}

Alanında sorgulayıcı bakış açısını kapsayacak şekilde ileri Eğitim öğretim süreçlerini etkin bir düzeyde kurumsal, metodolojik şekilde planlar.

Milli, manevi ve evrensel ve olgusal bilgiye sahiptir.

\begin{tabular}{lll}
\hline A2. Alan Eğitimi Bilgisi & B2. Öğrenme Ortamları Oluşturma & C2. Öğrenciye Yaklaşım \\
\hline $\begin{array}{l}\text { Alanının öğretim programına ve } \\
\text { pedagojik alan bilgisine } \\
\text { hâkimdir. }\end{array}$ & $\begin{array}{l}\text { Bütün öğrenciler için etkili } \\
\text { ögrenmenin gerçekleşebileceği } \\
\text { sağlıklı ve güvenli öğrenme ortamları } \\
\text { ile uygun öğretim materyalleri } \\
\text { hazırlar. }\end{array}$ & $\begin{array}{l}\text { Öğrencilerin gelişimini } \\
\text { destekleyici tutumlar sergiler. }\end{array}$ \\
\hline \multirow{2}{*}{$\begin{array}{l}\text { A3. Mevzuat Bilgisi } \\
\text { B3. Öğretme ve Öğrenme Sürecini } \\
\text { Yönetme }\end{array}$} & C3. İletişim ve İş Birliği \\
$\begin{array}{lll}\text { Birey ve öğretmen olarak görev, } \\
\text { hak ve sorumluluklarına ilişkin } \\
\text { mevzuata uygun davranır. }\end{array}$ & $\begin{array}{l}\text { Öğretme ve öğrenme sürecini etkili } \\
\text { bir şekilde yürütür. }\end{array}$ & $\begin{array}{l}\text { Öğrenci, meslektaş, aile ve } \\
\text { eğitimin diğer paydaşları ile etkili } \\
\text { iletişim ve iş birliği kurar. }\end{array}$ \\
\cline { 2 - 3 } & $\begin{array}{l}\text { Ölçme ve değerlendirme, yöntem, } \\
\text { teknik ve araçlarının amacına uygun } \\
\text { kullanır. }\end{array}$ & $\begin{array}{l}\text { Öz değerlendirme yaparak, kişisel } \\
\text { ve mesleki gelişimine yönelik } \\
\text { çalışmalara katılır. }\end{array}$ \\
\hline
\end{tabular}


Öğretmen yeterlikleri belgesiyle üniversitelerin öğretmen yetiştirmeye yönelik teorik ve uygulamalı derslerinin içeriklerini belirleme ve geliştirme yanında, istihdam edilecek öğretmenlerde aranacak nitelikler somut bir biçimde belirlenebilecek ve mesleğe kabul süreci yeterliklerle uyumlu biçimde düzenlenebilecektir (MEB, 2017:12). Ancak ne var ki; mesleğe kabul sürecinin yeterliklerle uyumlu biçimde düzenlenebilmesi için, alan ve alan eğitimi bilgisini ölçen ÖABT'ye ihtiyaç vardır ve ne yazık ki; sanat eğitimi alanında mesleğe kabul süreci, yeterliklerle uyum durumundan mahrumdur. Bu mahrumiyet, mesleki yeterliğin en önemli kriteri olan alan ve alan eğitimi donanımı ile ilgili lisans eğitimindeki teorik ve uygulamalı derslere verilen önemi de kendiliğinden yok etmektedir.

Nasıl ki, yükseköğretimde öğretmenlerin sahip olması gereken yeterliklerle donatılması yönünde eğitim verilmesi gerekiyorsa, öğretmen seçiminde de sahip olması gereken yeterliklere yönelik bir sınav sisteminin uygulanması kaçınılmazdır.

Öğretmen seçimi geçmişten günümüze kadar Milli Eğitim Bakanlığı tarafından uygulanan arz-talep anlayışı sonucu ortaya çıkan "Öğretmenlik Yeterlilik Sınavı", "Devlet Memurluğu Sınavı" (DMS), "Kamu Meslek Sınavı" (KMS) ve 2002 yılından itibaren yapılmakta olan "Kamu Personeli Seçme Sınavı" (KPSS) gibi sınavlar ile gerçekleştirilmiştir (Deryakulu, 2011; Dilekmen, Ercoşkun ve Nalçacı, 2005). Öğretmen adayları 2013 yllına kadar KPSS'de Genel Yetenek Testi (GYT) \%30, Genel Kültür Testi (GKT) \%30 ve Eğitim Bilimleri Testi (EBT) \%40 ağırlıklarında aldıkları puanla atanırken, bu tarihten itibaren kamu görevlerinde ilk defa atanacaklar için yapılacak sınavlar hakkında genel yönetmelikte yapılan değişiklikle Genel Yetenek Testi (GYT) \%15, Genel Kültür Testi (GKT) \%15 ve Eğitim Bilimleri Testi (EBT) \%20 ve Öğretmenlik Alan Bilgisi Testi (ÖABT) \%50 ağılıklarında bu testlerden aldıkları puanla atanacakları (ÖSYM, 2013)yönünde bir düzenleme gerçekleştirilmiştir.

Öğretmenlerden beklenen niteliklerin her geçen gün çeşitlendiği günümüz koşullarında bu sinavın amacı istenen niteliklere sahip en iyi öğretmenlerin seçimi olmalıdır (Atav ve Sönmez, 2013). Nitelikli öğretmenlerin yetiştirilmesi ve istihdamında ise öğretmen adaylarının seçimi önemli bir etkendir (Uygun, 2010). Bu konuya açıklık getirmek gerekirse; lisans öğrenimlerinde tabi oldukları genel yetenek, genel kültür, eğitim bilimleri ile alan ve alan eğitimi bilgisi derslerinin öğrenme çıtıları açısından yeterli donanıma sahip öğretmenlerin belirlenmesi ihtiyacından kaynaklanmaktadır.

Nitekim Baştürk (2007), “KPSS'de alan eğitimiyle ilgili soruların olmamasının eğitim fakültelerindeki "alan bilgisi ve eğitimi” ile KPSS arasında bir kopukluk yarattığını" belirtmektedir Çelik ve Kavak (2009) tarafından yurt dışında gerçekleştirilen öğretmen atamalarıyla ilgili sınavlar ve konu ile ilgili gerçekleştirilen araştırmalar dikkate alınarak; KPSS'nin içerik olarak öğretmen adaylarının kendi branşlarındaki alan bilgisini ölçebilecek bir sınav olmadığı, alan bilgisi ve alanların öğretimine ilişkin sorular içermemesinin büyük bir eksiklik olduğu belirtilmiştir. Atav ve Sönmez (2013); Elçiçek, Tösten ve Kılıç (2012) Gündoğdu, Çimen ve Turan (2008), KPSS'nin nitelikli öğretmeni seçebilecek özellikte bir sınav olmadığını; Çimen ve Yılmaz (2011) tarafından yapılan araştırmaya katılan öğretmen adaylarının çoğunluğu KPSS'nin alan sınavı eklenmemiş haliyle içerik açısından uygun olmadığını belirtmiştir. Şahin ve Arcagök (2010) ise KPSS'nin öğretmen adaylarının geleceklerine yön veren önemli bir sınav olduğunu, ancak nitelikli öğretmenleri belirleyemeyen gereksiz bir sınav olduğunu iddia etmiştir (Demir ve Bütüner, 2014)

MEB, (2013) ise; Öğretmenlik mesleğinin temel bilgi ve becerilerinin yanında kendi alanında da ileri düzey bilgi ve becerilere sahip öğretmenlere ihtiyaç duyduğunu belirtmektedir

Ancak ne var ki; son yıllarda artık pek çok öğretmenlik alanı için uygulanmaya başlanmış olan ve ağırlıklı puanı (\%50) kapsayan Öğretmenlik Alan ve Alan Eğitimi Bilgisi Testi (ÖABT), görsel sanatlar öğretmeni adaylarına uygulanmamakta, dolayısıyla da ataması yapılan kişilerin alanında yetkin öğretmenler olup olmadıkları ölçülememektedir. Mevcut Kamu Personeli Seçme Sınavı (KPSS)'de görsel sanatlar öğretmen adayları sadece genel yetenek - genel kültür ve eğitim bilimleri kısımlarına katılmakta ve bu kısımlardan aldıkları ortalama puan sıralamasıyla istihdam edilmektedirler.

$\mathrm{Bu}$ durumdan çıkan anlam şudur: Öğretmen adayının gerek "alanında sorgulayıcı bakış açısını kapsayacak şekilde ileri düzeyde kuramsal, metodolojik ve olgusal bilgiye sahip" (MEB, 2017:8)'olma durumunu açılayan 'Alan Bilgisi Yeterliği', gerekse de "Alanının öğretim programına ve pedagojik alan bilgisine sahip” (MEB, 2017:8) olup olmama durumunu açıklayan 'Alan Eğitimi Bilgisi Yeterliği' mevcut sınav sisteminde ölçülmemektedir.

$\mathrm{Bu}$ durum, lisans öğrenimlerine devam etmekte olan sanat eğitimi öğrencilerini öğrenim süreci içerisinde, alan ve alan eğitimi derslerine daha az önem vermeye yönlendirmektedir. Çünkü görsel sanatlar öğretmen adayları, mesleki hayata başlayabilme, yani atanabilme yarışında alan ve alan eğitimi bilgisine nasılsa ihtiyaçlarının olmadığını bilmektedirler. 
1739 sayılı Millî Eğitim Temel Kanunu'nun 43. Maddesi’nde; öğretmenliğin, eğitim öğretim ve bununla ilgili yönetim görevlerini üzerine alan özel bir ihtisas mesleği olduğu belirtilmektedir. Bu kanun öğretmenlik mesleğinin genel kültür, özel alan eğitimi ve pedagojik formasyon ile sağlandığını belirtmektedir (MEB, 2017). Kanunla da belirtilmiş olduğu üzere branşı ne olursa olsun her öğretmenin genel kültür, özel alan eğitimi ve pedagojik formasyon bilgisiyle donanmış olması gerekmekte, dolayısıyla nitelikli öğretmen seçiminde, öğretmen adaylarının bu üç alandan da yeterli olup olmadıklarını ölçmek adına sınava tabi tutulmaları gerekmektedir. Nitekim Türkiye'de öğretmenlik branşlarının çoğunda 2013 yılından bu yana bu üç alanı ölçecek nitelikte sınavlar gerçekleştirilmektedir. Genel yetenek - genel kültür ve pedagojik formasyon bilgisini ölçen eğitim bilimleri testi olan KPSS kapsamında, Öğretmenlik Alan ve Alan Eğitimi Bilgisini ölçen ÖABT (Öğretmenlik Alan ve Alan Eğitimi Bilgisi Testi) sınavı uygulanmaktadır.

Öğretmenlik alan bilgisi testi uygulanan branşlar: Türkçe, İlköğretim Matematik, Fen Bilimleri/Fen ve Teknoloji, Sosyal Bilgiler, Türk Dili ve Edebiyatı, Tarih, Coğrafya, Matematik (Lise), Fizik, Kimya, Biyoloji, Din Kültürü ve Ahlak Bilgisi, Yabancı Dil (Almanca, İngilizce), Rehber Öğretmen, Sınıf Öğretmenliği, Okulöncesi Öğretmenliği olarak belirlenmiştir (ÖSYM, 2017). Neredeyse, öğretmenlik branşlarının tamamına yakınana uygulanan söz konusu sınav, görsel sanatlar, müzik ve beden eğitimi gibi branşlardaki öğretmen seçiminde ÖABT olmaksızın yani alan ve alan eğitimi bilgisi ölçülmeksizin uygulanmaktadır.

Diğer branşlarda öğrenim gören öğretmen adayları, alan ve alan eğitimi konuları atama sistemlerinde ağırlıklı olarak (\%50) hesaplandığı için kendi branş derslerine önem verirken, sanat eğitimcisi adayları; Genel Yetenek (Türkçe, Matematik), Genel Kültür (Tarih, Coğrafya, Anayasa ve Türkiye ve dünya ile ilgili güncel konular) ve Pedagojik Formasyon konularına çalışmaktadır.

Lisans öğrenimlerinde tabi oldukları;

- Alan bilgilerini kapsayan; Sanat Tarihi, Sanat Felsefesi, Sanat Eleştirişi gibi sanat kültürü dersleri,

- Kuramsal alan bilgilerini de kapsayan; Temel Sanat Eğitimi, Desen, Perspektif ve Ana Sanat Atölye gibi uygulama dersleri,

- Alan eğitimi bilgilerini kapsayan Müze Eğitimi ve Uygulamaları, Özel Öğretim Yöntemleri ve Çocuğun Sanatsal Gelişimi gibi derslere ait bilgilerin yeterliği hiçbir şekilde ölçülmemekte, yani görsel sanatlar öğretmen adayları alan ve alan eğitimi yeterliğini ölçen ÖABT sınavına tabi tutulmamaktadır.

- 1739 sayılı Millî Eğitim Temel Kanunu (Madde, 43)’de belirtilen “Öğretmenlik mesleğine hazırlık genel kültür, özel alan eğitimi ve pedagojik formasyon ile sağlanır" ifadesinde yer alan "özel alan eğitimi” için görsel sanatlar öğretmenlerinin yeterliği ölçülmemektedir. Bu durumda, uygulanmakta olan sınavların amacı 'nitelikli öğretmen' seçmek olduğuna göre; görsel sanatlar öğretmenin sadece genel yetenek, genel kültür ve eğitim bilimleri konusunda yeterli olması kâfi midir? Yoksa nitelikli bir görsel sanatlar öğretmeninin öncelikli olarak alan ve alan eğitimi bilgisine mi sahip olması gerekmektedir? Hiç kuşku yok ki, alan ve alan eğitimi bilgisi kısmı; genel yetenek, genel kültür ve eğitim bilimleri testlerinden daha öncelikli olmalıdır. ÖABT'nin, diğer tüm branşlarda yapılıyor olması, sadece resim, müzik ve beden eğitimi alanlarında yapılmaması bu branşlarda alanında donanımlı öğretmen adayları açısından bir haksızlık değil midir? ÖABT, görsel sanatlar öğretmenliği branşı için niçin gerekli görülmemiştir? Bütün bunları özetleyecek olursak; amac1 "nitelikli öğretmen" seçmek olan mevcut sınav sisteminin verdiği mesaj "nitelikli bir görsel sanatlar öğretmeninin alan bilgisi ve alan eğitimi bilgisine sahip olmasına gerek yoktur” şeklinde algılanabilmektedir.

$\mathrm{Bu}$ araştırmanın amacı, görsel sanatlar öğretmeni istihdamında öğretmenlik alan bilgisi testinin gerekliliği ortaya koymak ve bu alan için KPSS'ye yönelik algı ölçeği geliştirmektir.

\section{YÖNTEM}

\section{Araştırma Modeli}

$\mathrm{Bu}$ araştırmada tarama modeli kullanılmıştır. Tarama geçmişte ya da halen var olan bir durumu, var olduğu şekliyle tespit etmeyi amaçlayan araştırma modelidir. Araştırmaya konu olan konu kendi koşulları içinde ve olduğu gibi tanımlanmaya çalışılır (Karasar, 2016).

\section{Çalışma Grubu}

Araştırmanın çalışma grubunu Gazi Üniversitesi, Gazi Eğitim Fakültesi, Güzel Sanatlar Eğitimi Bölümü, Resim - İş Eğitimi Anabilim Dalı'nda öğrenim görmekte olan 40 (\%28) 3. sınıf öğrencisi, 50 (\%35) 4. sinıf öğrencisi, $36(\% 25.2)$ pedagojik formasyon grubu öğrencisi ile $17(\% 11,8)$ mezun olmak üzere toplam 143 kişi oluşturmaktadır. Bu uygulamanın çalışma grubunda yer alan bireyler KPSS' ye girecek olan ve görsel 
sanatlar öğretmenliği branşında Milli Eğitim Bakanlığı'na bağlı kurumlarda çalışmayı hedefleyen öğretmen adaylarından amaçlı örnekleme yoluyla belirlenmiştir.

\section{Ölçeğin Geliştirme Aşamast}

Araştırmacılar tarafından ilgili literatür tarandığında literatürde yer alan çalışmalarda görüşme formları ve anket formlarının yer aldığı görülmüş ve konuyla ilgili bir ölçek olmadığı tespit edilmiştir. Görsel Sanatlar Öğretmeni Adayları İçin KPSS'ye Yönelik Algı Ölçeği'nin (Ek-1) geliştirilmesi aşamasında ilk olarak, alan uzmanları tarafından 35 maddelik madde havuzu oluşturulmuştur. $\mathrm{Bu}$ madde havuzunda yer alan maddeler harmanlanarak bir taslak ölçek geliştirilmiştir. Alan ve dil uzmanlarının incelemesi sonrasında madde havuzundaki 8 madde çıkarılarak 27 maddelik bir taslak ölçek formu hazırlanmıştır. Oluşturulan taslak ölçek, öğretmen adaylarının lisans öğrenimleri ve KPSS süreci, görsel sanatlar öğretmen adaylarının atama sistemine yönelik algılarına yönelik ifadeleri içermektedir. Geliştirilen taslak ölçek 143 öğretmen adayına uygulanmıştır. Maddelerin 18'si olumlu; 5'i ise olumsuz ifadeler içermektedir. Beşli likert formunda geliştirilen bu taslak ölçek tamamen katılıyorum (5), katılıyorum (4), kararsızım (3), katılmıyorum (2), hiç katılmıyorum (1) şeklinde derecelendirilmiştir. Faktör analizi yapılmadan önce olumsuz maddelerin puanları ters çevrilerek puanlama yapılmıştır.

\section{Verilerin Analizi}

Görsel Sanatlar Öğretmeni Adayları İçin KPSS’ye Yönelik Algı Ölçeği'nin güvenirlik ve geçerliğine kanıt oluşturmak için çeşitli analizler yapılmıştır. Ölçeğin yapı geçerliğine kanıt oluşturmak amacı ile Açımlayıcı Faktör Analizi (AFA) yapılmıştır. AFA için SPSS 21,0 paket programı kullanılmış ve bu analizde ölçekte yer alan maddelerin hangi faktörler ile ilgili olduğu ortaya çıkarılmıştır.

\section{BULGULAR}

Bu kısımda “Görsel Sanatlar Öğretmeni Adayları İçin KPSS’ye Yönelik Alg1 Ölçeği” için yapılan geçerlik ve güvenirlik çalışmalarına ilişkin bulgulara yer verilmiştir.

\section{Ölçeğin Geçerliğine İlişkin Bulgular ve Yorumlar}

Geliştirilen ölçeğin yapı geçerliğine ilişkin kanıt sağlamak amacıyla döndürülmüş temel bileşenler analizi yapılmıştır. Verilerin temel bileşenler analizine uygunluğunun belirlenmesi amacı ile Kaiser-Meyer-Olkin (KMO) katsayısı ve Barlett Sphericity testi değerleri hesaplanmıştır. 27 madde ile yapılan ilk açımlayıcı faktör analizi sonucunda maddelerin 4 faktör altında toplandığı ve ölçeğin gözlenen toplam varyansın \% 42,77'sini açıkladığı görülmüştür $\left(\mathrm{KMO}=.716 ; \mathrm{X}^{2}=1511,562 ; \mathrm{sd}=351 ; \mathrm{p}<, 001\right)$. Birden fazla faktöre yük veren maddelerin madde faktör yük değerleri arasında .20 'den az fark olan ve herhangi bir faktöre .30'un altında yük veren maddeler ölçekten çıkarılarak AFA tekrarlanmıştır. Toplamda 4 madde (M5, M6, M16, M21) ölçekten çıkarılmış, 3 faktörden oluşan 23 maddeli nihai form elde edilmiştir.

23 maddeden oluşan ölçeğin KMO değeri ,725 olarak hesaplanmış ve Barlett testi sonucu elde edilen chi-square test istatistiği sonucunun anlamlı olduğu görülmüştür $\left(X^{2}=1335,558 ; \mathrm{sd}=253 ; \mathrm{p}=, 000\right)$. Görsel sanatlar öğretmen adaylarının öabt algısı ölçeğinin açımlayıcı faktör analizi sonucunda elde edilen madde faktör yük değerleri, madde öz-değerleri ve açıkladıkları varyans oranları Tablo 2'de sunulmuştur.

Tablo 2 .

Görsel Sanatlar Öğretmen Adayları İçin KPSS Algısı Ölçeği’nin Faktörlerine Ait AFA Değerleri

\begin{tabular}{|c|c|c|c|}
\hline & $\begin{array}{l}\text { F1 } \\
\text { MFY* }\end{array}$ & $\begin{array}{l}\text { F2 } \\
\text { MFY }\end{array}$ & $\begin{array}{l}\text { F3 } \\
\text { MFY }\end{array}$ \\
\hline $\begin{array}{l}\text { M18. KPSS'de görsel sanatlar öğretmenliği seçimi için alan eğitimi } \\
\text { bilgisi sorularının gerekli olduğunu düşünüyorum. }\end{array}$ &, 777 & & \\
\hline $\begin{array}{l}\text { M22. ÖABT (Alan ve Alan Eğitimi Bilgisi Testi) uygulanarak istihdam } \\
\text { edilmiş görsel sanatlar öğretmeni, dersin kalitesini arttırır. }\end{array}$ & ,737 & & \\
\hline $\begin{array}{l}\text { M17. KPSS’de görsel sanatlar öğretmenliği seçimi için alan bilgisi } \\
\text { sorularının gerekli olduğunu düşünüyorum. }\end{array}$ & ,714 & & \\
\hline $\begin{array}{l}\text { M13. KPSS'de diğer branşlarda olduğu gibi Görsel Sanatlar branş1 } \\
\text { içinde öğretmenlik alan bilgisi testi (ÖABT) uygulanmalıdır. }\end{array}$ & ,687 & & \\
\hline
\end{tabular}


M23. ÖABT uygulanarak istihdam edilmiş görsel sanatlar öğretmeni, dersin amacına ulaşmasına katkı sağlar.

M27. KPSS'de görsel sanatlar öğretmen adaylarına ÖABT uygulanırsa lisans eğitiminde alan ve alan eğitimi derslerine verilen önem artar.

M14. ÖABT’nin yalnızca bazı branşlarda yapılıyor olmasııı bir haksızlık olarak görüyorum.

, 666

, 635

M15. Mevcut KPSS Görsel Sanatlar öğretmeni seçmek için uygundur.

M25. ÖABT kısmı Genel Yetenek, Genel Kültür ve Eğitim Bilimleri testlerinden daha öncelikli olmalıdır.

M19. Mevcut sınav sitemi nitelikli görsel sanatlar öğretmeni belirlemede yetersiz kaliyor.

M26. Mevcut KPSS görsel sanatlar öğretmen adaylarını alan ve alan eğitimi derslerine daha az önem vermeye yönlendirmektedir.

M20. Donanımlı görsel sanatlar öğretmeni Genel Yetenek, Genel Kültür ve Eğitim Bilimleri konusunda yeterli olması kâfidir.

M24. Sadece EĞT. BİL. İle GYGK sorularıyla seçilmiş olan görsel sanatlar öğretmenleri okullardaki görsel sanatlar dersinin tam olarak amacına ulaşmasına engeldir.

M10. GENEL YETENEK kısmı, genel yetenek bilgisini ölçecek niteliktedir.

M11. GENEL KÜLTÜR kısmı, genel kültür bilgisini ölçecek niteliktedir.

M12. EĞİTIMM BİLIMMLERİ kısmı, öğretmenlik bilgisini ölçecek niteliktedir.

M9. Öğretmen adaylarının EĞİTIM BİLIMLERİ bilgisi ölçülmelidir.

M8. Öğretmen adaylarının GENEL KÜLTÜR bilgisi ölçülmelidir.

M7. Öğretmen adaylarının GENEL YETENEK bilgisi ölçülmelidir.

M3. KPSS'de yer alan genel kültür sorularını çözmek için okulda aldığımız eğitim yeterlidir.

M2. KPSS'de yer alan eğitim bilimleri sorularını çözmek için okulda aldığımız eğitim yeterlidir.

M4. KPSS'de yer alan genel yetenek sorularını çözmek için okulda aldığımız eğitim yeterlidir.

, 770

, 756

, 634

, 609

, 518

, 461

M1. Lisans eğitimde aldığım eğitim dersleri KPSS'ye yöneliktir.

\begin{tabular}{lll}
\hline Faktörler & Madde Özdeğerleri (Eigen) & Açılanan Varyans \\
F1 & 4,94 & 21,48 \\
F2 & 3,18 & 13,81 \\
F3 & 2,26 & 9,81 \\
\hline
\end{tabular}

*MFY: Madde Faktör Yük Değeri.

Tablo 2 incelendiğinde açımlayıcı faktör analizi sonucunda görsel sanatlar öğretmeni adaylarının KPSS'ye yönelik algılarının üç faktörlü bir yapıda toplandığı görülmektedir. Bu faktörlerden ilki; 13, 14, 15, 17, $18,19,20,22,23,24,25,26$ ve 27 numaralı maddelerden oluşan "ÖABT'ye Yönelik Algılar" (F1) boyutudur. Bu boyut (F1) toplam varyansın 21,48'ini açıklamaktadır. Bir diğer faktör 7, 8, 9, 10, 11 ve 12 numaralı maddelerden oluşan "KPSS'nin Kapsamına Yönelik Algılar" boyutudur. Bu boyut (F2) toplam varyansın 13,81'ini açıklamaktadır. Ölçeğin son alt boyutu ise, 1, 2, 3 ve 4. Maddelerden oluşan "Lisans Öğrenimi ve KPSS Yeterliği Algısı" boyutudur. Bu boyut (F3) toplam varyansın 9,81'ini açıklamaktadır. Görsel Sanatlar Öğretmen Adayları İçin KPSS ve ÖABT Algısı Ölçeği'nin üç alt boyutu birlikte toplam varyansın 45,1'ini açıklamaktadır. 
Açımlayıcı faktör analizi sonucunda Tablo 1'de yer alan madde faktör yük değerleri incelendiğinde, ölçekte her bir maddeye ilişkin verilmiş olan madde faktör yük değerlerinin .388 ile .779 arasında değiştiği görülmektedir. Bir ölçme aracı geliştirme sürecinde madde faktör yük değerlerinin en az .30 olması gerektiği belirtilmektedir (Costello and Osborne, 2005). Bu değerler göz önünde bulundurulduğunda, ölçeğin madde faktör yük değerlerinin .30’un üzerinde olduğu görülmektedir.

\section{Ölçeğin Güvenirliğine İlişkin Bulgular ve Yorumlar}

Ölçeğin güvenirliğine ilişkin kanıt sağlamak amacıyla Cronbach Alfa (Cro) iç tutarlık katsayısı hesaplanmıştır. Yapılan güvenirlik analizleri sonucunda ilgili ölçeğin birinci alt boyutuna (ÖABT'ye Yönelik Algılar) ilişkin Cra katsayısı ,85; ikinci alt boyutuna (KPSS'nin Kapsamına Yönelik Algılar) ilişkin Cra katsayısı ,74; son olarak üçüncü alt boyutuna (Lisans Öğrenimi ve KPSS Yeterliği Algısı) ilişkin Cra katsayısı ,77 olarak bulunmuştur. Ölçeğin geneline ilişkin Cra katsayısı ise ,79 olarak bulunmuştur. Bir ölçme aracının güvenirliğinin olabilmesi için .70 yeterli bir kesme puan olarak görülmektedir (Nunnally, 1978; Creswell, 2012). Buna göre; ölçeğin güvenirliğine ilişkin kanıt sağlamak amacıyla yapılan güvenirlik analizi sonuçları, gerek alt boyutların gerekse ölçeğin bütününün mevcut haliyle iç tutarlılığı ve güvenirliği yüksek bir ölçme aracı olduğunu göstermektedir.

\section{SONUÇ VE TARTIŞMA}

Gelecekte, görsel sanatlar öğretmeni olarak atanmaktan başka şansı olmadığını düşünen lisans öğrencileri, lisans eğitimleri boyunca, öğretmen seçiminde tabi tutulacakları KPSS'ye yönelik bir anlayışla yaşamakta ve bu sistemde nasılsa işine yaramayacaklarını düşündükleri alan bilgisi ve alan eğitimi derslerine önem vermemektedir. Alan ve alan eğitimi derslerinde edindiği bilgilerin kalıcılığını sağlama ve ders notlarını yeniden gözden geçirme, muhafaza etme gibi bir kaygıları yoktur, nasılsa bir daha kendisine lazım olmayacaktır. Lisans eğitimi esnasındaki bu derslerin sınavlarında günü kurtarma çabası içerisinde ders notlarına biraz göz atıp, sadece dersten geçme çabası güden bir anlayış hâkim olmuştur. Atanabilmek için gerekli olan tek şey, alan ve alan bilgisini ölçmeyen KPSS sınav sisteminin gerektirdiği bilgilere sahip olabilmektir ve bu kadarı yeterlidir.

Dolayısıyla öğretmen adayları; galerileri, müzeleri, sergileri dolaşarak alanıyla ilgili donanım edinebilmek için değerlendirebileceği zamanı, sınav sisteminin gerektirdiği alan dişi bilgilere sahip olabilmek için kurslara giderek harcamayı tercih etmektedirler. Oysa ki; “....sanat eğitimcisi adaylarının galeri, sergi ve müze ziyaretleri gerçekleştirmeleri, tiyatro, opera, bale, sinema gibi diğer görsel sanat alanları ile ilişkiler kurmaları, sanat ile ilgili olan sempozyum kongre gibi etkinlikleri takip etmeleri, ülke ve dünya çapında olan genel gelişmelere duyarsız kalmayıp sanatsal gelişmeleri de takip ederek kendi entelektüel ve sanatsal kimliklerini oluşturabilmeleri gerekmektedir" (Çetin ve Bolu - Sert; 2016).

Akademik anlamda, ne kadar nitelikli görsel sanatlar öğretmeni yetiştirilmeye çalışılırsa çalışılsın, sanat ve sanat eğitimi bilgisine, donanımına ihtiyacı olmadığı mesajını veren atama sisteminde 1srar edilmesi nedeniyle bu konuda yeterince başarı elde edilememektedir. Üzüntü verici olan şu ki; bu durum yalnızca bizim alanımız için geçerlidir ve hemen hemen diğer tüm branşlarda öğretmenlik alan ve alan eğitimi bilgisi sınavı gerçekleştirilmektedir. Dolayısıyla mevcut sınav sitemi nitelikli görsel sanatlar öğretmeni belirlemede yetersiz kalmaktadır. Özetle denilebilir ki; ÖABT uygulanırsa hem lisans eğitiminde alan ve alan eğitimi derslerine verilen önem, hem de bununla bağlantılı olarak görsel sanatlar öğretmenlerinin niteliği artacaktır.

$\mathrm{Bu}$ araştırmada geliştirilen Görsel Sanatlar Öğretmen Adayları İçin KPSS Algısı Ölçeği, geçerlik ve güvenirliği kanıtlanmış bir ölçme aracı olduğundan ilgili alanda farklı üniversitelerde öğrenim görmekte olan ögrencilere uygulanarak karşılaştırmalı sonuçlar ortaya konulabilir.

\section{KAYNAKÇA}

Atav, E. \& Sönmez, S. (2013). Öğretmen adaylarının kamu personeli seçme sınavı (KPSS)’na ilişkin görüşleri. Hacettepe Üniversitesi Ĕ̆itim Fakültesi Dergisi, Özel Sayı (1), 01-13.

Baştürk, R. (2007). Türkiye'deki kamu eğitim kurumlarında çalışacak öğretmenlerin atanmalarına ilişkin bir inceleme. Hacettepe Üniversitesi Ĕ̈itim Fakültesi Dergisi 33, 33-40.

Costello, A. B., \& Osborne, J. W. (2005). Best practices in exploratory factor analysis: Four recommendations for getting the most from your analysis. Practical Assessment, Research \& Evaluation, 10(7), 1-9.

Çelik, K. \& Kavak, Y. (2009, Kasım). Ĕ̈itim fakülteleri ve KPSS-öğretmenlik sınavı sonuçları üzerine bir çalışma. Türkiye'nin Öğretmen Yetiştirme Çıkmazı Ulusal Sempozyumu'nda sunulmuş bildiri, Başkent Üniversitesi, Ankara. 
Çetin, A., G. \& Bolu - Sert, H. (2016, Kasım). Sanat eğitimcisi olarak yetişen ögrencilerin kültür sanat etkinliklerine ilgileri. Cumhuriyetin Işığında Yükseköğretimde Sanat Eğitimi Uluslararası Sempozyumu'nda sunulmuş bildiri. Gazi Üniversitesi, Ankara.

Çimen, O. \& Yılmaz, M. (2011). Biyoloji öğretmen adaylarının KPSS ile ilgili görüşleri, Gümüşhane Üniversitesi Sosyal Bilimler Elektronik Dergisi, 4, 159- 172.

Demir, S., B. \& Bütüner K. (2014) Sosyal Bilgiler öğretmen adaylarının alan sınavına yönelik görüşlerinin incelenmesi. Mersin Üniversitesi Eğitim Fakültesi Dergisi, 10(2), 113- 128.

Dilekmen, M., Ercoşkun, M. H. \& Nalçacı, A. (2005). Öğretmen adaylarının akademik ve KPSS başarılarının çeşitli değiş̧enler açısından incelenmesi. Kazım Karabekir Eğitim Fakültesi Dergisi, 11, 304 - 315.

Elçiçek, Z., Tösten, R. \& Kılıç, M. (2012). İlköğretim öğretmenlerinin Kamu Personeli Seçme Sınavı'na (KPSS) yönelik görüşlerinin belirlenmesi (Kars ili örneği), Dicle Üniversitesi Sosyal Bilimler Enstitüsü Dergisi 4(7), 109-123.

Gündoğdu, K., Çimen, N. \& Turan, S. (2008). Öğretmen adaylarının Kamu Personeli Seçme Sınavına (KPSS) ilişkin görüşleri, Ahi Evran Üniversitesi Kırşehir Eğitim Fakültesi Dergisi, 9(2), 35-43.

MEB (2017). Öğretmenlik Mesleği Genel Yeterlikleri. 21.02.2018 tarihinde http://oygm.meb.gov.tr/www/ ogretmenlik-meslegi-genel-yeterlikleri/icerik/39 sayfasından erişilmiştir.

Şahin, Ç. \& Arcagök, S. (2010, Mayıs). Sinıf öğretmeni adaylarının Kamu Personeli Seçme Sinavına (KPSS) ilişkin algıları. 9. Sınıf Öğretmenliği Eğitimi Sempozyumu'nda sunulmuş bildiri, Elazığ.

Uygun, S. (2010) Türkiye'de öğretmen adaylarının seçimi ile ilgili bazı uygulamaların tarihsel analizi. Gazi Eğitim Fakültesi Dergisi, 30(3) 707-730.

Uyulgan, M., A. \& Akkuzu N. (2015). Öğretmen adaylarının gözünden nitelikli öğretmen seçimi: ortaöğretim fen ve matematik alanları eğitimi bölümünde okuyan öğrencilerin durumu. Kastamonu Üniversitesi Kastamonu Eğitim Dergisi, 23(3) 917-940.

\section{Ek-1:}

Sayın görsel sanatlar öğretmen adayı,

Mevcut KPSS'de Görsel Sanatlar öğretmen adayları sadece Genel Yetenek - Genel Kültür ve Eğitim Bilimleri Kısımlarına katılmakta ve bu kısımlardan aldıkları ortalama puan siralamasiyla istihdam edilmektedirler. Diğer branşlar için ayrıca uygulanan ve ağırlıklı puanı (\%50) kapsayan Öğretmenlik Alan ve Alan Eğitimi Bilgisi Testi (ÖABT) branşınızdaki adaylara uygulanmamakta ve dolayısıyla alanında yetkin öğretmen olup olmadığı ölçülmemektedir.

Bu form Görsel Sanatlar Öğretmeni Adaylarının Lisans Öğrenimlerine, KPSS’ ye ve Atama Sistemine İlişsin Görüşlerini belirlemeyi amaçlayan 23 maddeden oluşmaktadır. Maddelere ilişkin görüşlerinizi 1 (Hiç Katılmıyorum) ile 5 (Tamamen Katılıyorum) arasında puanlayınız.

Katılımınız için teşekkür ederiz.

Görsel Sanatlar Öğretmen Adayları İçin KPSS Algısı Ölçeği

\begin{tabular}{|c|c|c|c|c|c|}
\hline \multicolumn{6}{|l|}{ Görsel Sanatlar Öğretmen Adayları İçin KPSS Algısı Ölçeği } \\
\hline & 嵀 & 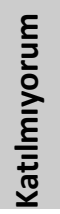 & 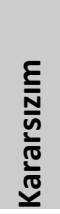 & 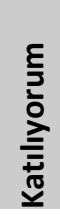 & 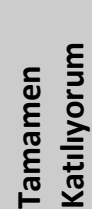 \\
\hline Lisans eğitimde aldığım eğitim dersleri KPSS'ye yöneliktir. & 1 & 2 & 3 & 4 & 5 \\
\hline $\begin{array}{l}\text { KPSS'de yer alan eğitim bilimleri sorularını çözmek için okulda aldığımız } \\
\text { eğitim yeterlidir. }\end{array}$ & 1 & 2 & 3 & 4 & 5 \\
\hline $\begin{array}{l}\text { KPSS'de yer alan genel kültür sorularını çözmek için okulda aldığımız eğitim } \\
\text { yeterlidir. }\end{array}$ & 1 & 2 & 3 & 4 & 5 \\
\hline $\begin{array}{l}\text { KPSS'de yer alan genel yetenek sorularını çözmek için okulda aldığımız } \\
\text { eğitim yeterlidir. }\end{array}$ & 1 & 2 & 3 & 4 & 5 \\
\hline Öğretmen adaylarının GENEL YETENEK bilgisi ölçülmelidir. & 1 & 2 & 3 & 4 & 5 \\
\hline Öğretmen adaylarının GENEL KÜLTÜR bilgisi ölçülmelidir. & 1 & 2 & 3 & 4 & 5 \\
\hline
\end{tabular}




\begin{tabular}{|c|c|c|c|c|c|}
\hline Öğretmen adaylarının EĞiTiM BiLiMLERi bilgisi ölçülmelidir. & 1 & 2 & 3 & 4 & 5 \\
\hline GENEL YETENEK kısmı, genel yetenek bilgisini ölçecek niteliktedir. & 1 & 2 & 3 & 4 & 5 \\
\hline GENEL KÜLTÜR kısmı, genel kültür bilgisini ölçecek niteliktedir. & 1 & 2 & 3 & 4 & 5 \\
\hline EĞiTiM BíLiMLERi kısmı, öğretmenlik bilgisini ölçecek niteliktedir. & 1 & 2 & 3 & 4 & 5 \\
\hline $\begin{array}{l}\text { KPSS'de diğer branşlarda olduğu gibi Görsel Sanatlar branşı içinde } \\
\text { öğretmenlik alan bilgisi testi (ÖABT) uygulanmalıdır. }\end{array}$ & 1 & 2 & 3 & 4 & 5 \\
\hline $\begin{array}{l}\text { ÖABT'nin yalnızca bazı branşlarda yapılıyor olmasını bir haksızlık olarak } \\
\text { görüyorum. }\end{array}$ & 1 & 2 & 3 & 4 & 5 \\
\hline Mevcut KPSS Görsel Sanatlar öğretmeni seçmek için uygundur. & 1 & 2 & 3 & 4 & 5 \\
\hline $\begin{array}{l}\text { KPSS'de görsel sanatlar öğretmenliği seçimi için alan bilgisi sorularının } \\
\text { gerekli olduğunu düşünüyorum. }\end{array}$ & 1 & 2 & 3 & 4 & 5 \\
\hline $\begin{array}{l}\text { KPSS'de görsel sanatlar öğretmenliği seçimi için alan eğitimi bilgisi } \\
\text { sorularının gerekli olduğunu düşünüyorum. }\end{array}$ & 1 & 2 & 3 & 4 & 5 \\
\hline $\begin{array}{l}\text { Mevcut sınav sitemi nitelikli görsel sanatlar öğretmeni belirlemede yetersiz } \\
\text { kalıyor. }\end{array}$ & 1 & 2 & 3 & 4 & 5 \\
\hline $\begin{array}{l}\text { Donanımlı görsel sanatlar öğretmeni Genel Yetenek, Genel Kültür ve Eğitim } \\
\text { Bilimleri konusunda yeterli olması kâfidir. }\end{array}$ & 1 & 2 & 3 & 4 & 5 \\
\hline $\begin{array}{l}\text { ÖABT (Alan ve Alan Eğitimi Bilgisi Testi) uygulanarak istihdam edilmiş görsel } \\
\text { sanatlar öğretmeni, dersin kalitesini arttırır. }\end{array}$ & 1 & 2 & 3 & 4 & 5 \\
\hline $\begin{array}{l}\text { ÖABT uygulanarak istihdam edilmiş görsel sanatlar öğretmeni, dersin } \\
\text { amacına ulaşmasına katkı sağlar. }\end{array}$ & 1 & 2 & 3 & 4 & 5 \\
\hline $\begin{array}{l}\text { Sadece EĞT. BiL. İle GYGK sorularıyla seçilmiş olan görsel sanatlar } \\
\text { öğretmenleri okullardaki görsel sanatlar dersinin tam olarak amacına } \\
\text { ulaşmasına engeldir. }\end{array}$ & 1 & 2 & 3 & 4 & 5 \\
\hline $\begin{array}{l}\text { ÖABT kısmı Genel Yetenek, Genel Kültür ve Eğitim Bilimleri testlerinden } \\
\text { daha öncelikli olmalıdır. }\end{array}$ & 1 & 2 & 3 & 4 & 5 \\
\hline $\begin{array}{l}\text { Mevcut KPSS görsel sanatlar öğretmen adaylarını alan ve alan eğitimi } \\
\text { derslerine daha az önem vermeye yönlendirmektedir. }\end{array}$ & 1 & 2 & 3 & 4 & 5 \\
\hline $\begin{array}{l}\text { KPSS'de görsel sanatlar öğretmen adaylarına ÖABT uygulanırsa lisans } \\
\text { eğitiminde alan ve alan eğitimi derslerine verilen önem artar. }\end{array}$ & 1 & 2 & 3 & 4 & 5 \\
\hline
\end{tabular}




\title{
The Visual Arts Teacher's Needs to Teacher's Knowledge Test for Employing Teachers and Perception Scale Development Study for PPSE
}

\author{
Meliha YILMAZ \\ Gazi University, Ankara//TÜRKIYYE \\ e-posta: ameliha@gazi.edu.tr \\ Kerim LAÇINBAY \\ Gazi University, Ankara//TÜRKIYE \\ e-posta: kerimlacinbay@gazi.edu.tr \\ Hüseyin ELMAS \\ Selçuk University, Konya/TÜRKIYE \\ e-posta: helmas@selcuk.edu.tr \\ Necmettin YAĞCI \\ Gazi University, Ankara//TÜRKIYE \\ e-posta:nyagci@gazi.edu.tr
}

Citation: Yılmaz, M., Laçinbay, K.., Elmas, H. \& Yağcı, N. (2018). The Visual Arts Teacher's Needs to Teacher's Knowledge Test for Employing Teachers and Perception Scale Development Study for PPSE. EKafkas Journal of Educational Research, 5(2), 40-49.

\section{Extended Summary}

Purpose and Significance: Education has so many important functions such as socialization; handing the current values to next generation; helping the individuals to discover and develop their abilities and talents, and to have professions by gaining them knowledge, skill and behaviors needed in order to help them survive and fit into society. Whether these functions work or not depends on the quality of teachers. Therefore, the only way to improve the outcomes of education is to improve the quality of teachers (MEB, 2017, s.1). One of the ways to improve the quality of education is the examination that evaluates the competency of teachers' knowledge, skills, attitudes and values. Because this brings up the efforts in order to get the adequate competency to begin the teaching profession. The purpose of this research is to reveal the necessity of testing teachers' knowledge in visual arts teacher employment and to improve the perception scale for this field PPSE. In the development stage of the scale, the study group constitutes 143 people studying at Gazi University, Gazi Education Faculty, Fine Arts Education Department, Visual Arts Education Department. 40 of them are 3rd year students, 50 are 4th grade students, 36 are pedagogical formation group students and 17 are graduated from related departments. This research is significant because both it demonstrates the necessity of field qualification examination for visual arts teacher employment and perception scale development for PPSE intended for candidates of teacher.

Methods: The survey method was used in this study. Survey method aims to determine a past or a present case as they are. The case that focused on is tried to describe within its terms (Karasar, 2016). The study group consisted of 143 teacher candidates. After the data collection process, exploratory factor analysis was used in order to determine the significant factors of the scale.

Results: When the literature is examined, the necessity TDPT (ÖABT) in the visual arts teacher employment has been revealed. As a result of the factor analysis, 4 items were extracted from the scale and a final form that consist of 23 items and 3 sub factors is created. The first of the sub-factors is called as "Perceptions for TDPT (ÖABT)", the second as "Perceptions for the Scope of PPSE" and the third as "Perception of Undergraduate Learning and PPSE Sufficiency". It can be seen that PPSE and TDPT Perception Scale for Visual Arts Teacher Candidates explains 45,1 of the total variance. As a result of the reliability analysis, the Cr $\alpha$ coefficient for the first sub-dimension is found to be 0.85; the Cra coefficient for the second sub-dimension is 0.74; and for the third sub-dimension the Cr $\alpha$ coefficient is 0.77 . The Cr $\alpha$ coefficient for the overall scale is 79 .

Discussion and Conclusions: It can be said that the relevant scale is a valid and reliable measuring instrument. This scale is available for those studying in the visual arts department of teaching in Turkey. The developed PPSE Perception Scale for Visual Arts Teacher Candidates is a valid and reliable scale, therefore it can be applied to students from other universities to make comparisons. 